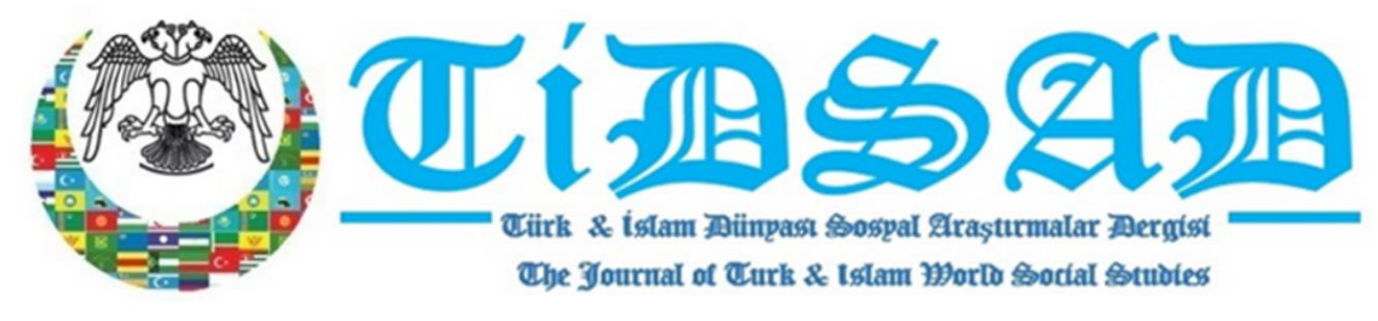

\title{
Sosyal Bilgiler Dersinde Coğrafya ile İlgili Kavramların Öğretiminde Model Küre Kullanımının Önemi
}

The Importance of the Use of the Model Sphere in Teaching Geography-Related Concepts in Social Studies Course

\section{Asım ÇOBAN*}

Pakize TAMUSTA**

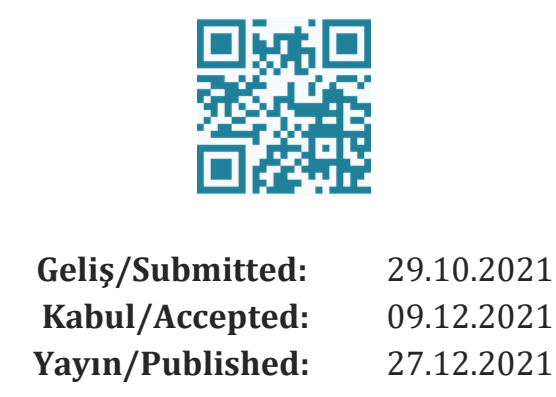

Citation / Atıf

Çoban, A. ve Tamusta, P. (2021). Sosyal Bilgiler Dersinde Coğrafya ile İlgili Kavramların Öğretiminde Model Küre Kullanımının Önemi. Türk \& İslam Dünyası Sosyal Araștırmalar Dergisi, 8 (31), 11-30.

Çoban, A. \& Tamusta, P. (2021). The Importance of the Use of the Model Sphere in Teaching Geography-Related Concepts in Social Studies Course. The Journal of Turk \& Islam World Social Studies, 8 (31), 11-30.

Makale Türü: $\quad$ Araştırma Makalesi $\quad$ Article Information: $\quad$ Research Article

10.29228/TIDSAD.54012

This article was checked by Intihal.net. Bu makale İntihal.net tarafindan taranmıştır.

This article is under the Creative Commons license. Bu makale Creative Commons lisansı altındadır.

*Prof. Dr., Amasya Üniversitesi, asim.coban@amasya.edu.tr

**Yüksek Lisans Öğrencisi, Amasya Üniversitesi, pakize.tamusta05@gmail.com 

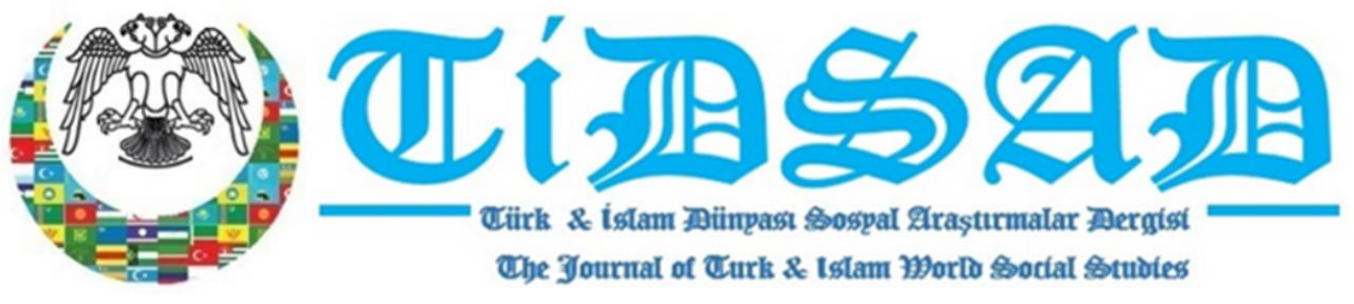

\title{
Sosyal Bilgiler Dersinde Coğrafya ile İlgili Kavramların Öğretiminde Model Küre Kullanımının Önemi ${ }^{1}$
}

\author{
The Importance of the Use of the Model Sphere in Teaching \\ Geography-Related Concepts in Social Studies Course
}

\section{Prof. Dr. Asım ÇOBAN Pakize TAMUSTA}

\begin{abstract}
Öz: Sosyal Bilgiler dersi kapsamında yer alan coğrafya kavramlarının öğretilmesinde model küre kullanımının önemini ortaya koymayı hedefleyen çalışma literatür taraması yöntemiyle yapılmıștır. Calıșma 3 ana bölümden olușmaktadır. İlk bölümde sosyal bilgilerde kavram öğretimiyle ve model küre kullanımıyla alakalı birçok nicel, nitel ve karma çalışmalar belirli kriterler dâhilinde incelenmiştir. Konuyla ilgili yapılan tez çalışmaları bilgisayar destekli tarama yöntemi kullanılarak incelenmiş ve tezlere 'Ulusal Tez Merkezi' aracıllı̆ı ile ulaşılmıștır. İkinci bölümde ise elde edilen bulgular not edilmiştir. En son bölümde ise elde edilen bulgularla ilgili çeşitli yorumlamalar ve analizler yapılmıștır. Araştırmanın sonuçlarına göre sosyal bilgiler ders müfredatında yer alan tarih, coğrafya, vatandaşlık vb. konuları içerdiği için oldukça kavram olarak oldukça zengin olan bir disiplin olduğu ve bunları öğretiminde öncelikle öğretmenlerin kavram öğretimine yönelmeleri gerektiği belirlenmiştir. Kavram öğretiminin ezbere dayalı öğretimin önüne geçtiği ve öğrenmenin kalıcılığını artırdığı tespit edilmiştir. Sosyal bilgiler dersinin kavramları incelendiğinde daha çok soyut kavramları içerdiği görülmüştür. Soyut kavramlarının öğreniminde ilkokul öğrencileri zorluk yaşamaktadırlar. Kavram öğretimiyle öğrencilerin zihnindeki soyut kavramları somutlaştırdığı gözlenmiştir. Sosyal bilgilerde kalıcılığı artıran bir önemli unsur da materyal kullanımı olduğu tespit edilmiştir. Özellikle coğrafya ile ilgili kavramları öğretirken model küre kullanımının çok faydalı olduğu ortaya konulmuştur. Derslerinde model küre ve harita kullanan öğretmenlerin, öğrencilerin dikkatini daha çabuk topladıklarını ve öğrencilerin ilgilerinin dağılmadığını gözlemlemişlerdir. Küreler gerçeğe en yakın materyallerdir. Öğrencilerin derslere olan katılımlarını artırarak aktif öğrenmeye destek olur. Bir önemli özelliği ise derslerin eğlenceli hale gelmesine katkı sağlar.
\end{abstract}

Anahtar Kelimeler: Sosyal bilgiler, kavram öğretimi, küre kullanımı.

1 “COPE-Dergi Editörleri İçin Davranış Kuralları ve En İyi Uygulama İlkeleri” beyanları: Bu çalışma için herhangi bir çıkar çatışması bildirilmemiştir. Bu çalışma için etik kurul onayı gerekmemektedir. Sorumlu Yazar: Asım ÇOBAN

Statements of "COPE-Code of Conduct and Best Practices Guidelines for Journal Editors": No conflicts of interest were reported for this article. Ethics committee approval is not required for this article. Corresponding Author: Asım ÇOBAN 


\begin{abstract}
The study aiming to reveal the importance of using model spheres in teaching geography concepts within the scope of Social Studies course was conducted with the method of literature review. The study consists of 3 main parts. In the first part, many quantitative, qualitative and mixed studies related to concept teaching and the use of model spheres in social studies were examined within certain criteria. Thesis studies on the subject have been examined using the computer-aided scanning method and the theses have been accessed through the "National Thesis Center". In the second part, the findings obtained were noted. In the last part, various interpretations and analyzes were made about the findings obtained. According to the results of the research, history, geography, citizenship etc. in the social studies course curriculum. It was determined that it is a very rich discipline because it includes subjects and that teachers should focus primarily on teaching concepts in teaching them. It has been determined that concept teaching prevents rote learning and increases the permanence of learning. When the concepts of the social studies course were examined, it was seen that it mostly included abstract concepts. Primary school students have difficulties in learning abstract concepts. It was observed that students concretized abstract concepts in their minds with concept teaching. It has been determined that an important factor that increases the permanence in social studies is the use of material. It has been demonstrated that the use of a model globe is very useful, especially when teaching concepts related to geography. They observed that teachers who used model spheres and maps in their lessons gathered students' attention more quickly and students were not distracted. Spheres are the material closest to reality. It supports active learning by increasing students' participation in classes. Another important feature is that it contributes to the fun of lessons.
\end{abstract}

Keywords: Social studies, concept teaching, model sphere usage.

\title{
Giriş
}

Sosyal bilgiler disiplini, sosyal bir varlık olan insanın geçmişi, günü ve geleceği ile bağ kurmalarında yol gösteren ve insanın sosyalleșmesine katkı sağlayan bir bilimsel disiplindir. İnsanlığın tarihsel süreçleri arasında bağ kurarken aynı zamanda bireyin çevresi ile etkileşimine ve vatandaşlık özelliklerine sahip olmasına da katkıda bulunur. Birey olmasının yanında toplumun bir parçası olmasına da yardımcı olur (Öztürk. 2006). İnsan faaliyetleri ve toplumsal ilişkilerin çok hızlı bir șekilde değiştiği günümüzde Sosyal bilgiler programlarının çağın gereklerine uygun olarak hazırlanması ve zaman içinde sürekli güncellenmesi büyük önem taşımaktadır. Bunun sonucu olarak da öğrenciler bu programı kolaylıkla hayatlarına ve çevrelerine uygulayabilmeli ve Sosyal Bilgiler Programı öğrencilere gerekli becerileri kazandırabilmelidir ( Paykoç, 1991: Öztürk, 2006: Sönmez 1998: Wiles \& Bondi.1993: Savaş, 1999).

Etkin vatandaşlık için sosyal bilgiler anlayışın savunucularından Sosyal Bilgiler Ulusal Konseyi (NCSS) sosyal bilgileri şu şekilde tanımlamıştır: "Sosyal bilgiler, vatandaşlık yeterliliklerini kazandırmak için sanat, edebiyat ve sosyal bilimlerin disiplinler arası bir yaklaşımla birleştirilmesinden oluşan bir çalışma alanıdır. Okul programı içinde Sosyal Bilgiler, antropoloji, arkeoloji, ekonomi, coğrafya, tarih, hukuk, felsefe, siyasal bilimler, psikoloji, din, sosyoloji ve sanat, edebiyat, matematik ve doğa bilimlerinden uygun ve ilgili içeriklerden süzülen sistematik ve eşgüdümlü bir çalışma alanı sağlar. Sosyal bilgilerin temel amacı, birbirlerine bağımlı, global bir dünyada, kültürel farklılıkları olan demokratik 
bir toplumun vatandaşları olarak kamu yararına bilgiye dayalı, mantıklı kararlar verebilme yeteneği geliştirmek için genç insanlara yardımcı olmaktır (NCSS, 1993, s.3)."

Sosyal bilgilerin içeriğinde birçok disiplinin bulunduğu alanı çok geniş olan bir programdır. Bu geniş alan, içerisinde yoğun bir şekilde kavram barındırmaktadır. Bu açıdan sosyal bilgilerde kavram öğretimi değer kazanmıştır. Özellikle coğrafya ile ilgili konular soyut kavramlar içermektedir. Soyut kavramların öğrenimi zor olduğu için somutlaştırılarak anlatılmaya ve öğretilmeye ihtiyaç duyulmuştur. Bu uygulamayı gerçekleştirmenin birinci yolu kavram öğretimidir. Kavram öğretimi materyallerle desteklendiğinde, öğrenmede ki kalıcılığını artırır. Bu materyallerden gerçeğe en yakın olanı "kürelerdir. Bu açıdan "model küreler" soyut bilgilerin somutlaştırılmasında, eğitime en büyük desteği olan materyallerdendir. Buna yönelik olarak derslerde model küre ve harita kullanımı artırılmalı ve sınıflarda araç-gereç olarak daha çok bulundurulmalıdır.

\subsection{Sosyal Bilgiler Programı Özel Amaçları}

1739 sayılı Millı̂ Eğitim Temel Kanunu'nda ifade edilen Türk Millı̂ Eğitimi'nin Genel Amaçları ve Temel İlkelerine uygun olarak şöyle ifade edilmektedir:

Sosyal Bilgiler Dersi Öğretim Programı ile öğrencilerin;

1. Türkiye Cumhuriyeti vatandaşı olarak vatanını ve milletini seven, haklarını bilen ve kullanan, sorumluluklarını yerine getiren, millı̂ bilince sahip birer vatandaş olarakyetişmeleri,

2. Atatürk ilke ve inkılaplarının, Türkiye Cumhuriyeti'nin sosyal, kültürel ve ekonomik kalkınmasındaki yerini kavrayıp demokratik, laik, millî ve çağdaş değerleri yaşatmaya istekli olmaları,

3. Hukuk kurallarının herkes için bağlayıcı olduğunu, tüm kişi ve kuruluşların yasalar önünde eşit olduğunu gerekçeleriyle bilmeleri,

4. Türk kültürünü ve tarihini oluşturan temel öge ve süreçleri kavrayarak millî bilincin oluşmasını sağlayan kültürel mirasın korunması ve geliştirilmesi gerektiğini kabul etmeleri,

5. Yaşadığı çevre ile dünyanın genel coğrafi özelliklerini tanıyarak insan ile çevre arasındaki etkileşimi açıklamaları ve mekânı algılama becerilerini geliştirmeleri,

6. Doğal çevrenin ve kaynakların sınırlılığının farkına varıp çevre duyarlılığı içerisinde doğal kaynakları korumaya çalışmaları ve sürdürülebilir bir çevre anlayışına sahip olmaları,

7. Doğru ve güvenilir bilgiye ulaşma yollarını bilen bireyler olarak eleștirel düşünme becerisine sahip olmaları,

8. Ekonominin temel kavramlarını anlayarak kalkınmada ve uluslararası ekonomik ilişkilerde millî ekonominin yerini kavramaları,

9. Çalışmanın toplumsal yaşamdaki önemine ve her mesleğin gerekli ve saygın olduğuna inanmaları,

10. Farklı dönem ve mekânlara ait tarihsel kanıtları sorgulayarak insanlar, 
nesneler, olaylar ve olgular arasındaki benzerlik ve farklılıkları belirlemeleri, değişim ve sürekliliği algılamaları,

11. Bilim ve teknolojinin gelişim sürecini ve toplumsal yaşam üzerindeki etkilerini kavrayarak bilgi ve iletişim teknolojilerini bilinçli kullanmaları,

12. Bilimsel düşünmeyi temel alarak bilgiye ulaşma, bilgiyi kullanma ve üretmede bilimsel ahlakı gözetmeleri,

13. Toplumsal ilişkileri düzenlemek ve karşılaştığı sorunları çözmek için temel iletişim becerileri ile sosyal bilimlerin temel kavram ve yöntemlerini kullanabilmeleri,

14. Katılımın önemine inanmaları, kişisel ve toplumsal sorunların çözümü için görüşler belirtmeleri,

15. İnsan hakları, ulusal egemenlik, demokrasi, laiklik, cumhuriyet kavramlarının tarihsel süreçlerini ve günümüz Türkiye'si üzerindeki etkilerini kavrayarak yaşamını demokratik kurallara göre düzenlemeleri,

16. Millî, manevi değerleri ile evrensel değerleri benimseyerek erdemli insan olmanın önemini ve yollarını bilmeleri,

17. Ülkesini ve dünyayı ilgilendiren konulara duyarlılık göstermeleri,

18. Özgür birer birey olarak fiziksel, duygusal özelliklerinin; ilgi, istek ve yeteneklerinin farkına varması amaçlanmaktadır.

Sosyal Bilgiler Dersi Temel Becerileri olarak ise: araştırma, çevre okuryazarlığı, değişim ve sürekliliği algılayabilme, dijital okuryazarlık, eleştirel düşünme, empati yapabilme, finans okuryazarlığı, girişimci olma, gözlem yapabilme, harita ve hukuk okuryazarlığ becerisi kazanma, iyi iletişim kurabilme, iş birliği yapabilme, medya okuryazarlığı, yenilikçi düşünme, problem çözebilme, karar verebilme, Türkçeyi düzgün ve etkin kullanabilme, mekanı algılayabilme ve zamanı verimli kullanma gibi becerilerin kazandırılması amaçlanmıştır. Esasen Sosyal Bilgiler dersleri sosyal bir varlık olan insanın istendik toplumsal tutum ve davranışlarının şekillenmesinde birincil etkenlerin başında gelmektedir.

\section{Yöntem}

Çalışmanın bu bölümünde araştırmanın yöntemi, çalışmanın amacl, problem cümlesi, çalışmanın sınırılıkları ve varsayımlarına yer verilecektir. Yöntem, özneyi doğruya en kısa yoldan götüren zihinsel ve dirik işlemsel süreçleri olarak tanımlanabilir (Sönmez, 2014.). Bu araştırma nitel araştırma olarak gerçekleştirilmiştir. Nitel araştırmada kullanılan doküman analizi gibi veri toplama teknikleri kullanılmıştır. Türk Dil Kurumu sözlügünde (2020) "belge" kelimesiyle karşıllk bulan, Oxford sözlüğünde (2020) ise bir şeyin kanıtı, bir şey hakkında bilgi veren resmi bir kağıt, kitap veya elektronik nitelikli bir dosya olarak tanımlanmaktadır. Doküman analizi kavramını Türkçe olarak söylemek gerekirse "belge incelemesi" demek doğru olacaktır (Kıral: $2020,173)$.

Doküman analizi, yazılı belgelerin içeriğini titizlikle ve sistematik olarak analiz 
etmek için kullanılan bir nitel araştırma yöntemidir (Wach, 2013). Doküman analizi, yazıll, görsel malzemenin toplanıp incelenmesidir. Sosyal bilgiler dersinde coğrafya kavramlarının öğretiminde model küre kullanımıyla ilgili betimsel bir çalışma gerçekleştirilmiştir.

\section{Araştırmanın Amacı ve Önemi}

Amaç, çalışmanın hangi bağlamda yürüyeceğinin ve özellikle süregelen çalışmalardan sentez yoluyla hangi boşlukların doldurulmak üzere hedef alındığının gösterilmesidir (Köroğlu, 2015.). Bu çalışmanın amacı: Sosyal bilgiler dersinde coğrafya kavramlarının öğrencilere öğretme sürecinde model küre kullanımının eğitimdeki etkisini araştırmaktır.

Araştırmanın önemi ise yapılan araştırma sonucunda etkin öğrenme-öğretme sürecine istenilen ölçekte katkı sağlayıp, sağlamadığının ortaya konulmasıdır.

Bu çalışmada Sosyal bilgiler dersinde, özellikle de coğrafi kavramların öğretiminde model küre kullanımının önemini ortaya konulması hedeflenmiştir. Çalışmadan elde edilen sonuçların etkin öğrenme-öğretme sürecine katkı sağlaması ve bu konuda yapılacak lisansüstü çalışmalara katkı sağlamak amaçlanmıştır.

\section{Problem Cümlesi}

Bir araştırma konusunda belirlenen hedef varmayı kolaylaştıran en önemli yaklaşım, çalışma konusundaki problem cümlesinin isabetli bir şekilde tespit edilmesidir. Bir araştırmanın temelini problem cümlesi oluşturur; çünkü tüm işlemler ona göre yapılır (Sönmez, 2014, s.271). Çalışmanın problem cümlesi şöyledir: "Sosyal bilgiler dersinde coğrafya ile ilgili kavramların öğretiminde model küre kullanımının önemi nedir?"

\section{Alt Problemler}

1. Sosyal bilgiler dersinde coğrafya ile ilgili kavramların öğretiminin önemi nedir?

2. Küre nedir? Kullanım alanları nelerdir?

3. Sosyal bilgiler dersinde küre kullanımın önemi nedir?

\section{Sinırlılıklar}

Araștırmanın nerede, hangi kurumda, kimler üzerinde ne zaman ve hangi değişkenlerle yapılacağının yazıldı̆̆ı kısımdır. Bunlar araştırmanın sınırını belirler. Eğer yazılmazsa, araştırmaya içinden çıkılmayacak kadar genişler, ya da çok daralır (Sönmez, 2014.).

1. Araştırma 2020-2021 öğretim yılı ile sınırlıdır.

2. Araştırma kullanılan tezler ve makaleler ile sınırlıdır.

\section{Sayıltılar (Varsayımlar)}

Bilimsel araştırmalarda doğruluğu kabul edilen, kanıtlanamayan; fakat akla uygun temel önermelere sayıltı denir (Sönmez, 2014.).Bu çalışmada da ölçme aracıyla elde edilen verilerin doğru olduğu ve katılımcıların araştırmaya objektif bir yaklaşımla katılım 
sağladıkları varsayılmıştır.

\section{Tanimlar}

Sosyal Bilgiler: İlköğretim programlarında bulunan Coğrafya, Tarih ve Yurttaşlık Bilgisi ile Sosyal Bilim dalları olan Antropoloji, Sosyoloji, Felsefe, Psikoloji, Ekonomi gibi disiplinlerin ilköğretimde uygun bir şekilde bir araya getirildiği konular bütünüdür (Kısakürek, 1998).

Eğitim: Bireyin davranışında, kendi yaşantısı yoluyla ve kasıtlı olarak istenilen yönde değişmeler meydana getirme sürecidir (Ertürk, 1972, s.12).

Öğretim Materyali: Öğretim materyalleri, eğitim yaşantısında eğiticiler tarafından farklı eğitim ortamlarında öğrencilere iletilen araç-gereçlerdir. Bu araç-gereçler öğrencilerin daha fazla duyu organına hitap edecek çeşitlilikteki eğitim ortamlarıdır (Kaya, 2005, s. 26; akt. Aküzüm, 2013.).

Kavram: İnsan zihninde anlamlanan, farklı obje ve olguların değișebilen ortak özelliklerini temsil eden bir bilgi formudur (Yel, 2012; Ülgen, 2001).

Kavram Öğretimi: Bir konu alanına ilişkin kavramların bilinmesi ile bu kavramlar arasındaki ilişkiler yeni öğrenilecek ya da öğretilecek konulara temel oluşturmaktır.

Küre: coğrafya konuları içerisinde yerin şekli, hareketleri, boyutları, eksen eğikliği, enlem, boylam, paralel, meridyen gibi konulardaki soyut ifadeleri somut hale getirmek için gerekli ve önemli olan bir araçtır (Güngördü, 2006: 368).

İlköğretim: Zorunlu eğitim çağındaki (6-14 yaş grubu) öğrencilere bir takım temel bilgi ve beceri kazandırılarak onları hayata ve bir sonraki eğitim kurumlarına hazırlayan bir eğitim evresidir (Erden, 1998).

\section{Sosyal Bilgiler ve Kavram Öğretimi}

Sosyal bilgiler, bireyin toplumda kendine bir yer edinebilmesi amaciyla insanın çevreyle olan etkileşimini farklı zaman bağlarında inceleyen, sosyal bilimler disiplinlerinden seçilmiş bilgilere dayalı olan ve birlikte öğretim anlayışına dayalı olarak kurgulanmış bir ilköğretim programıdır (MEB, 2005). Toplum, gündem, çağ her gün değişiklik göstermektedir. Ders programları, eğitim sistemleri de aynı ölçüde değişikliklere ve çağa ayak uydurmaya çalışmaktadır. Sosyal bilgiler programı oldukça güncel bilgileri içeren ve içeriğinde değişiklikler yapılmadığı takdirde çağın gerisinde kalınabilecek bir programdır. Dersin içeriği ve öğretmenleri her dönem kendini yenileyebilmelidir.

Yeni öğretim programında gelişen eğitim sistemlerine ayak uydurabilmek amacıyla kavramlara daha fazla yer vermiștir. Anlamlı ve kalıcı öğrenmeyi sağlamak için uygun yöntem ve teknikler haricinde bir de kavramların ve kavramlar arası ilişkilerin ortaya konulması gerekmektedir. Bilgiye giden yol kavramlardan geçmektedir. Kavramlar bilimselliği ve kalıcıllı̆ı artıran unsurlardır. Kavram, İnsan zihninde anlamlanan, farklı obje ve olguların değişebilen ortak özelliklerini temsil eden bir bilgi formudur (Yel, 2012; Ülgen, 2001).

Kavramlar bakımından oldukça zengin bir bilimsel disiplin olan Sosyal bilgiler 
derslerinde kavram öğretimi oldukça önemlidir. Sosyal Bilgiler derslerinde, özellikle de coğrafya konularında kavram öğretiminde genel olarak sunuş (geleneksel) ve buluş (modern) olarak bilinen öğretim yöntemleri daha çok kullanılmaktadır. Geleneksel (sunuş yoluyla) kavram öğretimi:

$\checkmark$ Önce kavramın tespiti

$\checkmark$ Kavram tanımının yapılması

$\checkmark$ Kavramı diğer kavramlardan ayıran ve farklılıklarını oluşturan niteliklerinin açıklanması

$\checkmark$ Kavramla ilişkili özellikle de güncel ve yakın çevreden örneklendirme yoluna gidilmesi.

Bu yöntemin öğrenmede ve öğretmede etkisi çok azdır. Nedeni ise kavramların sözel olarak tanımlarının tam olarak yapılamaması veya farklı tanımlamaların bulunmasıdır.

Etkili öğrenme-öğretme sürecinde kavram öğretimiyle ilgili yeni uygulamalar üzerinde durulmakta, farklı yöntemler geliştirilmektedir. Öğrenciye kavramı en iyi anlatan örnek verilmektedir ve buradan hareketle de genellemelere gidilmektedir. İlköğrenim düzeyindeki çocuklarda deneyimlerden yola çıkarak genellemelere gitme etkili olmaktadır. Günümüzde daha etkin olarak uygulanan modern (buluş yoluyla) öğrenme modeli J.S. Bruner tarafından geliştirilmiştir. Bu yönteme göre öğrenci bilgileri, kendi deneyimleriyle, bizzat eyleme dönüştürerek ve bireysel yaşamına tatbik ederek ve içinde bulunduğu ortamla ilişkilendirerek öğrenir. Buluş yoluyla öğrenmenin her aşamasında etkin ve kalıcı kavram öğretimi vardır.

Öğrencilerin sosyal bilgiler ile ilgili ilkeleri öğrenebilmesi ve toplumsal problemleri çözebilmesi için temel kavramları çok iyi kazanması gerekmektedir (Erden, Tarihsiz; 49).

\section{Kavram Öğretiminin Faydaları}

$\checkmark$ Kavram öğretiminin, öğrencilerin derslerindeki başarıları üzerinde olumlu etkileri vardır. Kavramların kavranması; ilerideki konuların daha iyi anlaşılmasına sebep olur ve öğrenilen kavramlar diğer derslerde de etkili olabilmektedir.

$\checkmark$ Kavram öğretimi yoluyla öğrenen öğrenciler, öğrendiklerini daha kolay hatırlarlar. Öğrenilen kavramların iletişim üzerinde olumlu etkileri vardır.

$\checkmark$ Eğitim ve öğretimde istenilen önemli bir konu öğretimin kişiselleşmesidir. Kavram öğretimi buna imkân sağlar.

$\checkmark$ Kavram öğretimi karşılaştırma yaparak gerçek öğrenmeleri sağlar ve yanlış algılamaları ortadan kaldırır.

$\checkmark$ Kavram öğrenimi karmaşık olan konuları somut hale getirerek daha iyi anlaşılmasına yardımcı olur.

$\checkmark$ Kavram öğretimi ile hatırlamanın ötesine geçilerek, problem çözme ve akıl yürütme gibi üst düzey düşünme becerileri gelişmiş olur. 
Sosyal bilgiler dersleri kapsamında doğru öğretilmesi hedeflenen kavramların farklı sınıf düzelerine göre dağılımına bakıldığında:

4. S Sinıf Sosyal Bilgiler dersi öğrenme alanlarında: 91

5. Sınıf Sosyal Bilgiler dersi öğrenme alanlarında: 121

6. Sınıf Sosyal Bilgiler dersi öğrenme alanlarında: 124

7. Sınıf Sosyal Bilgiler ders öğrenme alanlarında ise: 121

kavramın bulunduğu görülmektedir. Sosyal bilgiler dersinde toplamda 457 adet kavram bulunmaktadır. Ortaokullarda sınıf düzeyi arttıkça, öğrenme alanlarında yer alan coğrafya konularının kapsamları da genişlemektedir. Sınıf düzeylerine göre ünite adları değişebildiği gibi konu alanında da daha ayrıntılı bir nitelik kazanabilmektedir. 6.sınıf öğrenme alanlarında "Coğrafya ve dünyamız ile Türkiye"; 7.sınıftaki "Türkiye'nin Coğrafi Bölgeleri ve yurdumuzun komşuları" üniteleri özellikle temel coğrafya konularından oluşmaktadır.

\section{Sosyal Bilgiler Dersinde Coğrafya Kavramlarının Öğretimi}

İlköğretimde coğrafya eğitimi, sosyal bilgiler dersleri kapsamında ilkokul 4.sınıftan başlayıp, ortaokul 7.sınıfa kadar devam eden bir süreçte verilmektedir. Orta dereceli okullarda ise müstakil ayrı bir ders olarak verilmektedir. Coğrafya bir mekân bilimi olarak yeryüzünde bulunan ve yeryüzünü ilgilendiren coğrafi olgu ve olayları tanıtmak ve açıklamak için sık sık kavramların çok sık olarak kullanıldığı bir bilimsel disiplindir. Kavramların doğru kullanılması ve istenildiği şekilde anlașılması eğitimin etkili olmasına katkı sağlamaktadır. Coğrafyadaki kavramaların önemli bir kısmı soyut olduğundan dolayı, öğrenciler öğrenirken ve kalıcı hale getirirken zorluk yaşamaktadırlar.

Türkiye'de uygulanan coğrafya eğitim sisteminde kavram öğretimine yeterince yer verilmediği gözlenmiştir (Kolukısa, 2002: 24). Sistemlere bakıldığında ezberciliğin ön plana çıktığı ve geleneksel eğitimin uygulandığı gözlemlenmiștir. Ezbercilik ve kısa süreli öğrenmeler, öğrenmede en son istenen öğrenmelerdir. Eğitimin amacı kalıcı öğrenmeleri sağlamaktır. Burada eğitimcilere büyük görevler düşmektedir.

Eğitimcilerin derslerini anlatırken daha çok öğretim yöntem ve tekniklerine yönelmeleri gerekmektedir. Ders esnasında kullanılan harita, küre gibi eğitsel materyaller kullanmak, öğrencilerde öğrendiği bilginin kalıcılığını artıran yöntemlerdendir. Bu somut materyaller anlatılan konuları görselleştirir ve zihinde daha iyi yerleşmesini sağlar.

\section{6. ve 7. Sınıf düzeyinde okutulan Sosyal Bilgiler derslerinin Öğretim Progra- mında Yer Alan ve yaygın olarak kullanılan Coğrafya Kavramları}

Afet: Bu kavram pekiștirme düzeyindedir. Afetler, insanları için fiziksel, ekonomik ve sosyal kayıplara sokan, normal yaşantıyı durduran ya da kesintiye uğratan olaylar bütünüdür.

Beşeri Ortam: Bu kavram pekiştirme düzeyindedir. Beşeri ortam, insanlar tarafından oluşturulan doğal olmayan her türlü şeye denir.

Bölge: Bu kavram geliştirme ve pekiştirme düzeyindedir. Bölge, sınırları belir- 
lenmiş toprak parçasıdır.

$\checkmark$ Coğrafi Konum: Bu kavram geliștirme ve pekiștirme düzeyindedir. Coğrafi konum, herhangi bir noktanın, dünya üzerinde bulunduğu yerinin ortaya konulmasıdır.

Çevre: Bu kavram pekiștirme düzeyindedir. Çevre, bir yeri ya da bir șeyi dört bir yandan kuşatan yakın yerlerdir.

$\checkmark$ Çevre Kirliliği: Bu kavram pekiştirme düzeyindedir. Çevre kirliliği, çevreye ya da doğaya zarar veren her şeye çevre kirliliği denmektedir.

Doğal Kaynaklar: Bu kavram geliştirme ve pekiştirme düzeyindedir. Doğal kaynak, oluşumunda insan etkisinin olmadığı doğal ortam içerisinde kendiliğinde oluşan zenginliklerdir.

$\checkmark$ Doğal Ortam: Bu kavram pekiştirme düzeyindedir. Doğal ortam, canlı veya cansız varlıkların yaşadığı alandır.

Ekvator: Bu kavram giriş ve geliştirme düzeyindedir. Ekvator, kutup noktalarından eșit uzaklıkta yer alan ve kuzey-güney yönünde dünyayı iki eşit yarımküreye bölen en büyük çemberdir.

$\checkmark$ Enerji: Bu kavram geliştirme ve pekiştirme düzeyindedir. Enerji, iş yapabilme yeteneğidir.

$\checkmark$ Göç: Bu kavram geliştirme ve pekiştirme düzeyindedir. Göç; çeşitli sosyal, ekonomik, idari vb. sorunlardan dolayı insanların aile veya toplum olarak bulundukları bölgeden veya ülkeden ayrılmasıdır.

$\checkmark$ Harita: Bu kavram geliştirme ve pekiştirme düzeyindedir. Harita, dünyanın tamamının veya herhangi bir parçasının tam tepeden bakış dikkate alınarak belirli bir oran dâhilinde küçültülerek düzlem üzerine aktarılmasıdır.

$\checkmark$ İklim: Bu kavram pekiştirme düzeyindedir. Bir yerde uzun süre gözlenen meteorolojik olayların ortalamasıdır.

$\checkmark$ İskân: Bu kavram giriș ve geliștirme düzeyindedir. İskân, kelime manası olarak yerleşmedir.

$\checkmark$ Keşif: Bu kavram geliştirme düzeyindedir. Keşif, bilinmeyen bir şeyi ortaya çıkarmadır.

$\checkmark$ Kıta: Bu kavram geliştirme düzeyindedir. Kıta, dünyada geniş alan kaplayan ve birbirlerinden genellikle okyanuslarla ayrılan karasal alanlardır.

$\checkmark$ Kutup: Bu kavram giriş ve gelişme düzeyindedir. Kutup, yerküreyi ikiye ayıran ekvator dairesine en uzak olan kuzey ve güney olarak ikiye ayrılan noktadır.

$\checkmark$ Küresel Sorun: Bu kavram giriş ve gelişme düzeyindedir. Küresel sorun, dünya üzerindeki herkesi ilgilendiren sorunlardır. (Küresel ısınma gibi)

$\checkmark$ Nüfus: Bu kavram geliştirme pekiştirme düzeyindedir. Nüfus; bir ülkede, bölgede veya yerde yaşayan insanların tümüdür. 
Okyanus: Bu kavram giriş ve geliştirme düzeyindedir. Okyanus, anakaraları birbirinden ayıran büyük denizdir.

$\checkmark$ Ölçek: Bu kavram geliştirme düzeyindedir. Ölçek, bir yerin haritadaki uzunluğu ile gerçek uzunluğunun birbirine olan oranıdır.

$\checkmark$ Sanayi: Bu kavram geliştirme ve pekiştirme düzeyindedir. Sanayi, teknolojik üretim faktörlerinin kullanılarak seri ve ekonomik mal üretme faaliyetlerinin genel adıdır.

$\checkmark$ Şehirleşme: Bu kavram geliştirme ve pekiştirme düzeyindedir. Şehirleşme, kırsal kesimlere yapalı sanayi ve iş gücü yatırımlarıyla bu alanlarda yapılan değişikliklere denir.

$\checkmark$ Turizm: Bu kavram geliştirme ve pekiştirme düzeyindedir. Turizm, bir yeri görmek, eğlenmek, dinlenmek amacıyla yerli ve yabancı ziyaretçilerin yaptığı gezilerdir.

$\checkmark$ Ulaşım: Bu kavram geliştirme ve pekiştirme düzeyindedir. Ulaşım, bir yerleşim yerinden, başka bir yerleşim yerine gitmedir.

$\checkmark$ Yerleşme: Bu kavram pekiştirme düzeyindedir. Yerleşme, İnsanların oturduğu ve faydalandığı bölgedir.

$\checkmark$ Yön: Bu kavram pekiştirme düzeyindedir. Yön, bir yere gitmek için izlenecek istikamettir.

Sosyal bilgiler dersinde kullanılan 6.ve 7.sınıf kavramları bunlardır. Bu kavramların öğretimi, dersin doğru öğrenilmesi ve kalıcıllğı için önemlidir.

\section{Sosyal Bilgiler Dersinde Model Küre Kullanımı}

Model küreler coğrafyanın konuları içerisinde daha çok yerin şekli, hareketleri, boyutları, eksen eğikliği, enlem, boylam, paralel, meridyen gibi konulardaki soyut ifadeleri somut hale getirmek için gerekli ve önemli olan bir araçtır (Güngördü, 2006: 368).

\section{Model kürelerin gösterdiği unsurlar:}

$\checkmark$ Ülkelerin siyasi sınırları

$\checkmark$ Okyanus akıntılarının dağılışını

$\checkmark$ Yer şekillerini

$\checkmark$ Önemli şehirler merkezlerini

$\checkmark$ Hava ulaşım hatlarını

$\checkmark$ Uluslararası deniz taşımacılığı ana güzergâhlarını gösteren 3 boyutlu materyallerdir.

Küre üzerindeki renkler yardımıyla yükselti ve okyanuslardaki derinliklerin hangi bölgelerde arttığı ve hangi bölgelerde azaldığı rahatlıkla anlaşılır. Fiziki ve beşeri dağılımların gösterilmesi, model kürelerle daha net ve daha anlaşılır olmaktadır.

Model küreler coğrafya dersinde kullanılan materyallerdendir. Coğrafya dersi içeriğinde soyut kavramlar barındıran bir derstir. Bundan dolayı eğitimde çeşitli materyaller kullanılarak soyut olan kavramlar somutlaştırılmaya çalışılır. Örneğin paralel ve meridyenleri öğretmek isteyen bir eğitici, bu kavramların sadece kelime manasını 
söyleyip, teorik olarak tanımını yaptığında etkili öğrenmenin gerçekleşmeyip, öğrenilen bilginin hızlı bir şekilde unutulmasına sebep olmaktadır. Bunun yerine eğitimcinin, kavramları küre üzerinde göstermesi hem öğrencinin dikkatini çeker, hem de öğrencide bilginin daha uzun süre kalıcılığını artırır.

\section{Model kürelerin kullanılabileceği konular:}

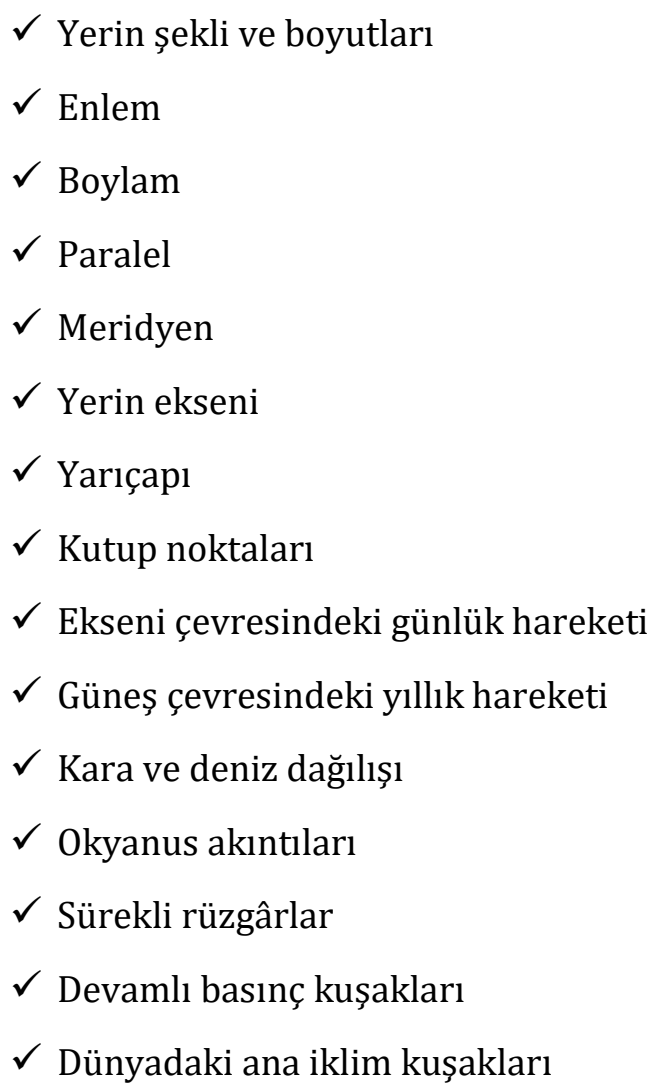

gibi konular etkili bir şekilde işlenebilmektedir. Özellikle soyut coğrafya konularının daha kolay anlaşılması için somutlaştırılma sürecinde model küreler oldukça işlevsel olup, gerekli ve önemli bir öğrenme aracıdır.

\section{Model Küre Çeşitleri}

Eğitimde kullanılan birçok model küre şekilleri vardır. Bunlar eğitim kademlerine göre değişiklik göstermektedir.

\section{Basit Küreler}

Basit küreler, içeriğinde ayrıntıyı en az barındıran küre çeşididir. Kullanım alanı eğitime yeni başlayanlardır. Gösterdiği unsurlar ise daha çok ülkelerin başkentleri, kara ve deniz dağılışı, okyanuslar ve denizlerdir. Çok karmaşık olmayan, göz yormayan ve kolay öğrenimi sağlayan materyallerdir.

\section{Orta Düzey Küreler}

Sosyal bilgiler dersinde yoğun olarak kullanılan materyallerdir orta düzey küreler. Düzeyi, 4. 5.ve 6.sinıflara uygundur. Basit kürelere göre içeriği daha geniştir. Fakat gelişmiş kürelere göre ayrıntısı daha azdır. 


\section{Gelişmiş Küreler}

Gelişmiş küreler, içeriğinde çok fazla ayrıntı barındıran kürelerdir. İlköğretim düzeyindeki çocuklarda kullanılması doğru değildir. Bu küreler, içeriğinde çok sayıda ülke, şekil, bölge vb. unsurlar barındırır. Ortaöğretim ve üst kademlerinde kullanılması uygundur.

\section{Küre Kullanmanın Avantajları}

Model küreler, öğrencilerin farklı alanların coğrafi konumunu daha iyi kavramalarına yardımcı olur. Öğrenciler model küreler üzerinde kara parçalarını, deniz ve okyanusları somut bir biçimde görür ve kolaylıkla karşılaştırma yapma imkânı bulur. Öğrenciler küreler üzerinde yaşadıkları ülkeyi, ülkenin coğrafi konumunu ve dünya üzerindeki yerini doğru ve kolay bir biçimde tespit edebilir.

Küre üzerindeki değişik alanlar özgürce görülebilir. Küreler dönebilen açıları değiştirilebilen materyallerdir. Bu yüzden kullanımı da eğlencelidir. Küreler ile hayali olan, görsellik kazanmış olur. Kürelerin üzeri işaretlenebilir ve silinebilirdir. Bu yönüyle eğitimi dokunsallaştırır.

Model küreler kıtaların, okyanusların ve denizlerin dağılışını, aralarındaki mesafeyi ve yer şekillerini belli bir oranda küçültülerek gerçeğe en yakın bir şekilde gösterilebilme özelliğine sahiptir. Dünyanın kendine has şeklinden dolayı düzlem üzerine aktarılmasında gerçekleşen gerçek değerlerdeki bozulmalar kürelerde korunabilmektedir. Hatasız harita yapımı mümkün değilken, model küre yapımı mümkün olabilmektedir.

Öğrenciler model küreyi materyal olarak kullandıklarında dünyanın günlük ve yıllık hareketini daha kolay kavrayabilmekte, eksen eğikliğinin değişmediğini ve eksen eğikliğinin sonuçlarını daha kolay kavrayabilmektedir. Coğrafya öğretiminde kullanılan model küreler sayesinde öğrenciler dünyanın kendi ekseni etrafındaki hareketi sırasında, ekvatordaki dönüş hızının kutuplardan hızlı olduğunu daha kolay anlarlar (Güngördü, 2006).

Model küreler üzerinden öğrenim almış bir öğrenci, coğrafi soruları doğru cevaplamaktadır. Kürelerden bilgi üretebilmektedir. Ekonomik aktiviteleri kürelere bakarak yorumlayabilmektedir.

Küreler üzerinde yoğunlaşan öğrenciler ülkelerin konumlarını ve isimlerini daha iyi öğrenmektedir. Küreler üzerindeki yönler sayesinde bazı işaretlerin ne anlama geldiği öğrenilebilmektedir. Doğal kaynaklar ve akıntılar tespit edilebilmektedir. Dünya üzerindeki devamlı basınç merkezleri, buna bağlı olarak ta sürekli rüzgârlar ve etki alanları daha doğru ve kalıcı bir biçimde öğrenilebilmektedir. Yine dünyadaki ana iklim kuşakları, ana toprak kuşakları, doğal bitki topluluklarının yayılış sahaları daha kolay öğrenilmekte, öğrenilen bilgi daha kolay hatırlanmaktadır.

Etkili öğrenme-öğretme sürecinde eğitsel materyal kullanmanın sağladığı kolay ve kalıcı Sembollerin anlaşılması öğrenmeye Sosyal Bilgiler derslerinde yer alan coğrafya konularının öğretiminde model küre kullanımının da birçok faydası bulunmaktadır. Model küre kullanımı derse motivasyonu artırdığı gibi, öğrencilerin eğlenerek öğrenmelerine de katkı sağlayan önemli bir öğrenme materyalidir. Öğrenciler soyut olan bazı coğrafi 
kavramların küre ve haritalar sayesinde somutlaștırılmasıyla daha kolay ve kalıcı bilgiye ulaşma imkânı bulacaklardır.

\section{Küre Kullanma Becerisi}

Öğrenme-öğretme sürecinde gerek harita gerekse model küre kullanımı becerileri ile ilgili olarak farklı kaynaklarda benzer değerlendirmelerin yapıldığı görülmektedir.

McClure (1992: 101) ise harita ve küre kullanım becerilerini şöyle sıralamıştır:

$\checkmark$ Alansal perspektifin geliştirilmesi

$\checkmark$ Yönün anlaşılması

$\checkmark$ Uzaklığın anlaşılması

$\checkmark$ Yerin belirlenmesi

$\checkmark$ Harita ölçeği

$\checkmark$ Yeryüzü şekillerinin anlaşılması

$\checkmark$ Haritanın yorumlanması

Özellikle model küre kullanımında coğrafi kavramlar ve onların doğru yorumlanabilmesi çok önemlidir. Bunlardan bazıları semboller, konum, yön bulma, ölçek ve uzaklık, karşılaştırma ve çıkarım yapmadır. Harita ve küre kullanımında öncelikle semboller öğretilir ve anlaşılır. Daha sonra alansal perspektif geliştirilir.

Haritalar üzerindeki okların hangi yönü gösterdiği anlaşılır. Konumlar arasındaki uzaklıklar belirginleşir. Ölçeğin ne olduğu somut bir şekilde anlaşllır. Yeryüzündeki şekillerin neyi ifade ettiği anlaşılır. En sonunda bu özellikler bilinerek haritalar ve küreler yorumlanır.

\section{Model Kürelerin Özellikleri}

Model küreler üzerindeki mesafeler bellidir ve aradaki mesafeler ölçülebilir. Model kürelerin üzerindeki yönler ve arazi değerleri korunmaktadır. Ayrıca haritaya nazaran model kürelerdeki bozulma oranı çok azdır. Model kürelerde açı, uzunluk ve alan değerleri yanında yön genel olarak eksiksiz olarak gösterilebilmektedir.

Model kürelerin taşınması ve saklanması güçtür. Üretimleri haritalara kıyasla daha pahalıdır. Model kürelerin baskı ve çoğaltma imkânı bulunmamaktadır. Bundan dolayı da eğitim ortamlarında haritalardan daha az bulunmaktadır.

Model küreler haritalar gibi içeriğinde çok fazla ayrıntı bulundurmazlar ve haritalara göre daha büyük ve hantallardır.

Model kürelerin özellikle okyanus akıntıları, sürekli rüzgâr yönleri, devamlı basınç merkezlerinin yanında, ekvator, eksen, kutup noktaları, enlem, boylam, meridyen ve paralel gibi soyut kavramların daha kolay anlaşılması ve açıklanmasında önemli bir yeri vardır.

İlköğretim kademelerindeki çocuklara model küreler; yakınlık, uzaklık, büyüklük, küçüklük, kuzey, güney, doğu, batı gibi tanımların kavratılmasına yardımcı olur. 
Öğrencilerin model küreler üzerindeki hususları bilmeleri kendi toplum ve ülkelerinin, dünya ile olan bağlantısını anlaması açısından da önemlidir (Gardner, Demirtas ve Doğanay, 1997).

Model küreler eğitim ortamlarında daha az kullanılan materyallerdir. Sınıflardaki küreler de öğretmenlerin izni olmadan kullanılmaz. Bu durum eğitim ortamlarında istenmeyen bir durumdur.

Model küreler ile hem dersler eğlenceli hale gelir ve küreler öğrencinin dersteki dikkatini toplamaya yardımcı olmaktadır. Küreler, öğrenilen şeylerin kalıcılığını sağlamada çok etkili olan materyallerdir.

\section{Sosyal Bilgiler Dersinde Küre Kullanımın Önemi}

Güngördü (2006: 368) küre için, coğrafya konuları içerisinde yerin şekli, hareketleri, boyutlarl, eksen eğikliği, enlem, boylam, meridyen, paralel gibi konulardaki soyut ifadeleri somut hale getirmek için gerekli ve önemli olan bir araç ifadesini kullanmıştır.

Sosyal bilgiler programı; coğrafya konularını da içeriğinde barındıran bir disiplindir. Coğrafya kavramlarının temelinin öğrenildiği ders sosyal bilgiler dersidir. Bundan dolayı ilköğretim çocuklarına sosyal bilgiler dersi verilirken, bazı coğrafi kelimelerin doğru kavratılması gerekmektedir ve bilgiler kalıcı olmalıdır.

Bilgilerin kalıcılığı için yapılması gerekenlerden biri, eğitimcilerin derslerinde gerekli ve etkili olan materyalleri kullanmasıdır. Coğrafya eğitimi için en çok kullanılan ve tercih edilen materyaller: haritalar ve kürelerdir.

Kürelerle eğitim dokunaksallaşır ve somutlaşır. Küreler hayali kavramların zihinde oturmasına yardımcı olur. Küre kullanmadan anlatılan soyut coğrafi kavramların zihinde kalıcılığı çok azdır. Kısa bir süre sonunda, ilköğretim çocuklarının ezberlediği bilgiler hafızalarından silinecektir.

Küreleri gören, dokunan ve küreyi yakından tanıma imkanı bulan çocuklar dünya ile ilgili bazı kavramları daha çabuk kavrarlar. İleride ayrı bir disiplin olarak coğrafya dersi ile karşılaştığında zorlanmaz ve kalıcı bir biçimde kazanılmış olan bilgilerini ilerletmekte, ezber yapan akranlarına nazaran daha başarılı olacaktır.

Küreler görsel bir araç-gereçtir. Küreler, ilköğretim seviyesindeki öğrencilerin hem oyalanmasını sağlar, hem de eğlenerek öğrenmesini sağlar. İlköğrenimde, coğrafya öğreniminde küre kullanımının en uygun olduğu ders sosyal bilgiler dersidir. Sosyal bilgiler dersinde, dünya ile ilgili anlatılabilecek bazı konular (örneğin: paralel, meridyen, ülkelerin konumları...), küre ile daha somut hale getirilip anlatılabilmektedir.

Küre ile öğrenen çocuklar, coğrafyayı ve dünyayı daha kolay anlar. Öğrenciler değişik bakış açıları kazanır. Küre üzerinde değisşik alanlar özgürce görülebilir. Kürelerin açıları değiştirilebilir.

Harita ve küre birbirinin ayrılmaz parçalarıdır. Bu nedenle beceriler içerisinde, harita ve küre kullanım becerisi olarak ortak bir kullanım bulunmaktadır. Detaylı anlatımlarda harita kullanılmaktadır. Küreler, derslerde öğrencilerin dikkatini haritalardan daha çok çekmektedir. 
Kürelerin, öğrencilerin dikkatini çekmesinden dolayı eğitim öğretim kademelerinde haritalardan önce kullanılması gerekmektedir. Kürelerin haritalara göre anlaşılırlığı daha kolaydır. Küreler, haritalara göre daha görseldir.

Haritalar iki boyutludur. Küreler ise üç boyutludur. Bu açıdan ilköğretim çağındaki çocuklar küreyi daha iyi anlarlar. Haritalara baktığında öğrenciler kafa karışıklığına düşmektedir. Çünkü dünya üzerindeki şekillerin nasıl kâğıda aktarıldığıyla ilgili durum öğrencilerde karmaşaya sebep olmaktadır.

Küre üzerinde denizler, karalar, enlem-boylam çizgileri gibi şekiller yer almaktadır. Bunların öğrenimini kolaylaştırmak için öğrencilere küre üzerine tebeşirle veya silinebilir kalemle işaretleme yapmalarına imkân sağlanmalıdır.

Küreler içeriğinde pek çok bilgiyi barındırmaktadır. Bu bilgiler, sosyal bilgiler dersindeki coğrafi kavramların temelidir. Öğrenciler, dünyanın hareketlerini küre üzerine bakarak öğrenebilirler. Örneğin: Öğretmen küreyi yukarı kaldırıp: "Bu bizim üzerinde yaşadığımız gezegenimizin şeklidir" der ve devamında öğrencilere küre üzerindeki yaşadığı ülkeyi göstermelerini sağlayabilir. Bu gibi sınıf içi uygulamalarla öğrencilerin dikkatini çekerek, bu tarz uygulamalı öğrenme-öğretme sürecinde öğrencilerin küreye dokunma ve küreyi inceleme firsatı elde etmeleri sağlanabilmektedir.

\section{Küre İle İșlenebilecek Ders Örnekleri}

\section{Örnek: 1}

Düzey: 5. Sınıf

Ders: Sosyal Bilgiler Dersi

Öğrenme Alanları: Küresel Bağlantılar

Ünite: Hepimizin dünyası

Kazanım: Çeşitli ülkelerde bulunan ortak miras ögelerine örnekler verir.

1. Aşama: Öğrencilere ortak miras ögelerinin neler olduğu ve bunların bulunduğu yerler söylenir.

2. Aşama: Örneğin: Pizza Kulesi, Piramitler, Eyfel Kulesi, Taç Mahal, Özgürlük Anıtı, Kremlin Sarayı, Çin Seddi, Orhun Anıtlarının yerleri küre üzerinde öğretmen tarafından gösterilir.

3. Aşama: Daha sonra küre üzerindeki ülkelere, ortak miras ögelerinin fotoğrafları yapıştırılır.

4. Aşama: Karışık yapıştırılan bu fotoğrafları öğrenciler tarafından düzenlenmesini ve doğru yerlere takılması istenir.

5. Aşama: Öğrencilerle birlikte öğretmen, ortak miras ögelerini ve bulunduğu yerleri tekrar eder. 


\section{Örnek 2}

Öğrencilerin, dersten sıkıldığı zamanlarda ya da dersin dikkat çekme bölümünde sınıfça küre üzerinde ülke bulmaca oyunu oynatılabilir. Öğretmen ya da öğrenciler bir ülke söyler, seçilen öğrenci de küre üzerinden o ülkeyi bulmaya çalışır. En sonunda ise söylenen ülkeyi en kısa zamanda bulan öğrenciye ödül verilebilir.

\section{Örnek 3}

Dünyanın kendi ekseni etrafındaki hareketi ve bu hareketin sonuçları küre ile öğretilebilir. Dünyanın hareketleri küre üzerinde öğretilecek en önemli konulardan biridir. Öğrencilerin bunu başka türlü kavramaları çok zordur.

1. Aşama: Dünyanın kendi ekseni etrafında batıdan doğuya doğru hareket ettiği, bu günlük hareketinin sonucunda gece-gündüz oluştuğu kolaylıkla anlatılır.

2. Aşama: Bunu anlatmak için fener ve küreyle örnek bir uygulama yapılabilir. Örneğin; sınıfın ışıkları kapatılır ve her küre başındaki öğrencilerden birinin eline bir fener verilerek, bu feneri küre üzerine tutmaları istenir. Bu sırada da küre batıdan doğuya doğru (saatin tersi yönünde) hareket ettirilir.

3. Aşama: Öğretmen kürenin kuzey ve güney kutup noktalarından tutarak dünyanın batıdan doğuya doğru sürekli kendi etrafında döndüğünü açıklar. Bir nokta işaret edilerek, bu noktaya fener ışığının eğik gelmesinden yola çıkılarak güneş ışınlarının da aynı şekilde geldiği belirlenir. Işınların eğik geldiğinde bu zaman diliminin sabah olduğu, fener tam karşıdan tutularak güneş ısınlarının giderek yükseldiği ve tam tepe noktasına geldiğinde ise zamanın öğle olduğu, fener daha da batıya hareket ettirilip, tekrar ışığın eğik gelmeye başladığına dikkat çekilerek de bu vaktin akşam olduğu vurgulanır. Işığa göre gölgede kalan alanların ise geceyi yaşamakta olduğu somut olarak ortaya konulabilmektedir.

Çeşitli uygulamalarda ve etkinliklerde küre kullanılabilir. Uygulamalar öğrencilerin dikkatini çekecek ve dersteki aktivitelerini arttıracaktır. Yaparak-öğrenerek öğrenen öğrencilerdeki bilgiler daha kalıcı olmaktadır.

\section{SONUÇ VE ÖNERILLER}

Sosyal bilgiler dersi, içeriğinde çok fazla kavram barındırmaktadır. Bu kavramlar yeni gelen nesillere öğretildiğinde ve özümsettirildiğinde, geleceğimiz konusunda maddi, manevi ve milli konularda farkındalığın artmasına katkıda bulunan gençler yetiştirilecektir. Gelecek nesillerin bilgi birikimiyle donanımlı olarak yetişmelerini sağlamak için sosyal bilgiler dersinin temelde iyi kavratılması gerekmektedir.

Sosyal bilgiler dersi içeriğinde barındırdığı kelimeler dolayısıyla soyut bir programdır. İlköğretim öğrencileri, böyle dersleri öğrenirken zihinlerine oturtmakta zorluk yaşamaktadırlar. Öğrencilerin paraleller ve meridyenler gibi soyut unsurları, görmediği şehirleri, okyanusları vb. kavramları öğrenirken zorluk yaşadıkları bilinmekte olup, bu türlü zorlukları ortadan kaldırmak için de öğretmenlerin derslerini işlerken materyallerden etkin olarak yararlanmaları büyük önem taşımaktadır.

Sosyal bilgiler programı içerisinde tarih, coğrafya, ekonomi, siyaset, antropoloji, 
sosyoloji, sosyal psikoloji, vatandaşlık, felsefe, iletişim, arkeoloji gibi birçok disiplin barındıran bir derstir. Böylesine içeriğinde bilimsel disiplinler açısından zenginlik barındıran bir dersin, yeni nesillere en güzel şekilde aktarılması büyük önem arz etmektedir.

Soyut konuların öğretilmesinde yapılan en büyük hata öğrencilere kavramları ezberletmektir. Ezberlenen kavramlar, kısa süre sonra unutulmaktadır. Bunun önüne geçmek için kavram ve genelleme odaklı öğrenim yapmak gerekmektedir. Kavram öğretimi, iletişimin basitleşmesine ve kolaylaşmasına yardımcı olur. Ezbere öğrenim hatırlamaya dayalıdır. Kavram öğretimi ile üst düzey düşünme becerileri kazandırılmış olur. Bilginin kalıcılığı artırılmış olur.

Kavram öğretimi sürecinde materyaller, çok önemli öğrenme araçlarıdır. Materyaller soyut olan bilgiler ve kavramları somutlaştırarak eğitime katkı sağlamaktadır. Coğrafya kavramlarını öğretirken kullanılan materyallerden biri haritalar ve model kürelerdir. Özellikle paralel, meridyen, enlem ve boylam gibi soyut kavramların somutlaştırılması için materyal olarak model kürelerin kullanımı zorunluluk oluşturmaktadır. Bașta iklim kuşakları, iklim kuşaklarına paralel olarak uzanan doğal bitki kuşakları, dünyanın günlük hareketine bağlı olarak zaman kavramının küresel dağılışı ancak model küre üzerinde anlaşılabilir olmakta, kalıcı öğrenmeyi kolaylaştırmaktadır.

Kürelerin öğrenme-öğretme sürecinde mutlaka kullanılması gereken konulardan birisi de dünyanın hareketleri konusudur. Dünyanın gerek günlük, gerekse yıllık hareketinin konu olarak ele alındığı öğrenme alanının her safhasında birincil materyal tereddütsüz model küreler olmalıdır. Hem konunun daha kolay anlaşılması, hem de kalıcı öğrenmenin gerçekleşmesinde model kürelerin kullanılması konuyu somutlaştıracak ve etkili öğrenmeye malzeme oluşturacaktır.

Materyaller içinde model küreler, coğrafya için oldukça önemlidir. Öğretmenler derslerinde model küreleri kullanarak öğrencilerin derse olan dikkatini toparlayabilirler. Küreler şekil olarak dikkat çeken ve ilgi gösterilen bir materyaldir. Bu yüzden öğretmenlere, derslerinde coğrafya ile ilgili konuları işlerken bazı kavramlarda model küreleri kullanmaları gerektiği önerilmektedir.

Küreler gerçeğe en yakın olan materyallerdir. Öğrenciler dokunabilir, üzerine işaretleme yapabilir ve silebilirler. Öğretmenler, öğrencilerin model kürelere dokunup, onlarla oynanmasına izin vermelidir. Kürelerle temasta bulunmak ve onlarla oynamak eğitimin daha eğlenceli hale gelmesine yardımcı olmaktadır.

Oyun, öğrenciler için her zaman cazip bir aktivitedir. Küreler üzerinde oynanan ülke bulmaca gibi oyunlarla öğrencilerin derse olan katılımları artırılmalıdır. Öğrenciler işaktivite ile derslerini öğrenmiş olur, bu da istenilen bilginin kalıcılığını artırmış olacaktır.

İlköğrenim düzeyindeki çocuklara coğrafya ile ilgili kavramlar anlatılırken, model kürelere daha çok yer verilmelidir. Ülkemizde genel olarak model kürelerin bir okulda bir ya da iki tane bulunduğu, bunlarında çoğu zaman sınıflara götürülmediği bilinen bir gerçektir. Küre kullanımı öğretmenin izni ile kullanılmakta, öğretmen tarafından getirilmekte ve götürülmektedir. Çoğu öğrenci öğrenim hayatı boyunca bu kürelere dokunmadan, bilmeden öğrenimini tamamlamaktadır. Öğrencilerin küre ile teması daha 
çok sağlanmalı ve eğitimde kürelere daha çok yer verilmelidir. Gerekirse her sınıf ortamında bir model kürenin devamlı olarak bulundurulması sağlanmalıdır.

Sadece okul ortamlarında değil, evlerde de model küreler olmalıdır. İlk ve orta dereceli okullarda öğrenim görmekte olan çocukların çalışma odalarının duvarlarında mutlaka bir dünya, bir de Türkiye haritası bulundurulmalı, çalışma masasında da model küreye yer verilmelidir. Öğrencilerin çalışma odalarına harita ve model küre kazandırılması için çeşitli faaliyetler yapılmalı ve toplumsal dayanışma teşvik edilmelidir.

\section{KAYNAKÇA}

Erden, M. (1998). Eğitimde Program Değerlendirme. Ankara: Anı Yayıncılık.

Erden, M. (Tarihsiz). Sosyal Bilgiler Öğretimi. Ankara: Alkım Yayınları.

Ertürk, S. (1972). Eğitimde Program Geliştirme. Ankara: Hacettepe Üniversitesi Yayını.

Gardner, W., Demirtas, A. ve Doğanay, A. (1997). İlköğretim Sosyal Bilgiler Öğretimi. Kaynak Üniteler. Öğretmen Eğitimi Dizisi. Ankara: MEGEP.

Güngördü, E. (2002). Coğrafyada Öğretim Yöntemleri, İlkeler ve Uygulamalar. Ankara: Nobel Yayın Dağıtım.

Güngördü, E. (2006). Coğrafya Öğretim Yöntemleri ve Çağdaş Öğretim Yaklaşımları (2. baskı). Ankara: Asil Yayınları.

Kıral, B. (2020). Nitel Bir Veri Analizi Yöntemi Olarak Doküman Analizi. Siirt Üniversitesi Sosyal Bilimler Enstitüsü Dergisi, 15, 170-189.

Kısakürek, M. A. (1988). Sosyal Bilgiler Öğretiminin Niteliği, Kapsamı ve Amaçları. Sosyal Bilgiler Öğretimi. Eskişehir: T.C. Anadolu Üniversitesi Yayınları.

Kolukısa, E. A. (2002). Coğrafya Eğitim Programlarının Temel Bilgiler ve Terimlerin Verilmesinde Karşılaşılan Bazı Güçlükler ve Bunlara Yönelik Çözüm Önerileri. Kastamonu Eğitim Dergisi, 10(2), 359-365.

McClure, R. W. (1992). A Conceptual Model For Map Skills Curriculum Development Based Upon A Cognitive Field Theory Philosophy, Oklahoma State University (Yayınlanmamıs Doktora Tezi), Oklahoma.

Milli Eğitim Bakanlığı. (2005). İlköğretim Sosyal Bilgiler Dersi 4-5. ve 6-7. Sınıflar Öğretim Programı. Ankara: MEB Yayınları.

NCSS (National Council for the Social Studies). (1993). Position statement: A vision of powerful teaching and learning in the social studies: Building social understanding and civic efficacy. Social Education 57(5), 213-23.

Oxford Sözlügü. (2020). https://www.oxfordlearnersdictionaries.com/ 17.08.2021 tarihinde erişilmiştir.

Öztürk, C. (2006). Sosyal bilgiler: Toplumsal Yaşama Disiplinler Arası Bir Bakış C. Öztürk (Editör), Hayat Bilgisi ve Sosyal Bilgiler Öğretimi (s. 22-49). Ankara: Pegem A Yayıncıllk. 
Paykoç, F. (1991). Tarih öğretimi. Eskişehir: A. Ü. A.Ö.F. Yay.

Sönmez, V. ve Alacapınar, F. G. (2014). Örneklendirilmiş Bilimsel Araştırma Yöntemleri. Anı Yayıncıllk.

Türk Dil Kurumu Sözlüğü. (2020). https://sozluk.gov.tr/17.08.2021 tarihinde erişilmiştir.

Ülgen, G. (2001). Kavram Geliştirme ve Uygulamalar (3.Baskı). Ankara: Pegem A Yayınları.

Wach, E. (2013). Learning about qualitative document analysis. opendocs.ids.ac.uk

Yel, S. (2012). Kavram geliştirme ve öğretimi. Bulunduğu eser: Öztürk, C.(Ed.) Sosyal Bilgiler Öğretimi (3.Baskı) (ss. 111-143) Ankara: Pegem Akademi. 